\title{
PENGARUH JENIS PUPUK ANORGANIK TERHADAP PERTUMBUHAN DAN HASIL TANAMAN SAWI PAGODA (Brassicaee narinosa L.)
}

\section{EFFECT OF INORGANIC FERTILIZER TYPE OF THE GROWTH AND YIELD OF PAGODA MUSTARD (Brassicaee narinosa L.)}

\author{
Tia Syifa, Selvy Isnaeni*, Arrin Rosmala
}

Program Studi Agroteknologi, Fakultas Pertanian, Universitas Perjuangan Tasikmalaya Jl. PETA No. 177, Kahuripan, Tawang, Kota Tasikmalaya 46115 - Indonesia

*Korespondensi : isnaeniselvy20@gmail.com

\begin{abstract}
ABSTRAK
Produksi sawi pagoda pada saat ini masih terbatas, sedangkan kebutuhan pasar semakin meningkat. Salah satu upaya peningkatan hasil dan produktivitas tanaman sawi pagoda yaitu pemupukan untuk meningkatkan kesuburan tanah dan meningkatkan ketersediaan unsur hara dalam tanah sehingga pertumbuhan tanaman lebih produktif. Penelitian ini bertujuan untuk mengetahui pengaruh pemberian jenis pupuk serta untuk mengetahui dosis pupuk yang optimal terhadap pertumbuhan dan hasil tanaman sawi pagoda (Brassicae narinosa L). Rancangan yang digunakan adalah Rancangan yang digunakan adalah Rancangan Kelompok Lengkap Teracak (RKLT) dengan 10 perlakuan dan 3 ulangan. Hasil penelitian menunjukkan respon pemberian jenis pupuk anorganik terhadap pertumbuhan dan hasil tanaman sawi pagoda (Brassicaee narinosa L.) pada parameter luas daun $\left(33,91 \mathrm{~cm}^{2}\right)$ memberikan pengaruh nyata sedangkan pada parameter lainnya tidak berpengaruh nyata. Dosis pupuk urea $333 \mathrm{Kg} \mathrm{Ha}^{-1}$ memberikan luas daun tanaman terluas, yaitu sebesar $33,91 \mathrm{~cm}^{2}$.
\end{abstract}

Kata kunci: pemupukan, pupuk anorganik, sawi pagoda

\begin{abstract}
Cabbage mustard production is currently limited, while the market needs are increasing. One of the efforts to increase yield and productivity of mustard pagoda is fertilization to increasevsoil fertility and increase the availability of nutrients in the soil so that plant growth is more productive. This research aims to determine the effect of the type of fertilizer as well as to determine the optimal dose of fertilizer on growth and yield pagoda mustard plant (Brassicae narinosa L). The experiment was conducted in an randomized complete block design with 10 treatments and 3 replications. The results showed that administration of inorganic fertilizers of the growth and yield of pagoda mustard (Brassicaee narinosa L.) has significant effect on the broad parameters of the leaf while the other parameters were not significant. Dose of fertilizer urea at a dose of $333 \mathrm{Kg} \mathrm{Ha}^{-1}$ is the treatment that gives the plant leaf area $33.91 \mathrm{~cm}^{2}$.
\end{abstract}

Keywords: fertilization, inorganic fertilizers, pagoda mustard

\section{PENDAHULUAN}

Pertanian di Indonesia memiliki berbagai jenis komoditas tanaman yang dapat di budidayakan dan dikembangkan untuk pemenuhan kebutuhan sehari-hari. Salah satu komoditas tanaman hortikultura yang dapat dibudidayakan di Indonesia 
yaitu tanaman sawi. Berdasarkan data statistik pertanian secara nasional kemampuan produksi tanaman sawi Indonesia pada tahun 2017 sebesar 10,27 Ton $\mathrm{Ha}^{-1}$. Sedangkan untuk Jawa Barat produksi sawi sebesar 16,20 Ton $\mathrm{Ha}^{-1}$ dengan luas panen 13.348 Ha dan produksi tanaman sawi di Tasikmalaya sebesar 5,64 Ton/Ha dengan luas lahan 168 Ha (BPS Jawa Barat, 2017). Terdapat prospek pengembangan budidaya salah satu sawi yang sangat cerah untuk memenuhi kebutuhan dalam negeri yaitu sawi pagoda. Sawi pagoda layak untuk dibudidayakan di Indonesia, karena dilihat dari aspek klimatologis, aspek teknis, aspek ekonomi dan aspek sosialnya sangat mendukung.

Tanaman sawi mengandung kandungan gizi yang tinggi meliputi protein, lemak, karbohidrat, Ca, P, Fe, Vitamin A, Vitamin B, dan Vitamin C yang memiliki peranan penting untuk kesehatan (Irmawati, 2018). Pada saat ini diketahui produksi sawi pagoda masih terbatas, sedangkan kebutuhan pasar semakin meningkat. Salah satu upaya peningkatan hasil dan produktivitas tanaman sawi pagoda yaitu pemupukan untuk meningkatkan kesuburan tanah dan meningkatkan ketersediaan unsur hara dalam tanah sehingga pertumbuhan tanaman lebih produktif.

Tanaman sawi memerlukan unsur hara yang cukup dan tersedia bagi pertumbuhan dan perkembangannya untuk menghasilkan produksi yang maksimal.
Salah satu unsur hara yang sangat berperan pada pertumbuhan daun adalah Nitrogen (N). Sumber hara N yang banyak digunakan adalah Urea. Pemberian dosis urea yang optimal pada tanaman akan menentukan pertumbuhan dan hasil tanaman sawi.

Pemupukan tanaman sawi selain menggunakan pupuk urea dapat juga menggunakan pupuk NPK dan pupuk daun Gandasil D. Pupuk NPK mengandung unsur hara nitrogen, posfor, dan kalium dan baik untuk mendukung masa pertumbuhan tanaman dan unsur hara yang disumbangkan dapat memenuhi kebutuhan hara tanaman. Pupuk daun Gandasil D mengandung unsur hara nitrogen, posfor, dan kalium yang dilarutkan dalam air sehingga dapat dengan mudah diserap dan ditranslokasikan keseluruh bagian tanaman, dan mampu mendukung proses pertumbuhan dan perkembangan tanaman.

Dosis perlu diteliti karena tanaman memiliki kebutuhan unsur hara dalam jumlah yang berbeda untuk menunjang pertumbuhan dan perkembangan serta hasil yang optimal. Tidak semua dosis bersifat positif bagi tumbuhan, kelebihan pupuk dapat bersifat toksik bagi tanaman, sedangkan kekurangan pupuk atau unsur hara dapat menyebabkan penyakit defisiensi unsur hara. Penelitian ini bertujuan untuk mengetahui pengaruh pemberian jenis perlakuan pemupukan yang optimal terhadap pertumbuhan dan hasil tanaman sawi pagoda (Brassicae narinosa L). 


\section{BAHAN DAN METODE}

Bahan yang digunakan dalam penelitian ini yaitu benih tanaman sawi pagoda, tanah, air, pupuk NPK mutiara, pupuk urea, pupuk gandasil D dan polibag. Alat yang digunakan dalam penelitian ini cangkul, meteran untuk mengukur tinggi tanaman dan diameter batang, timbangan, gelas ukur dan label.

Penelitian ini menggunakan Rancangan Acak Kelompok (RAK) faktor tunggal dengan perlakuan jenis anorganik yaitu pupuk NPK Mutiara, urea, dan Gandasil D. Perlakuan dalam penelitian ini terdiri dari tanpa pemupukan, pupuk NPK Mutiara, pupuk urea dan pupuk Gandasil D. Perlakuan diulang tiga kali dengan setiap masing-masing unit perlakuan terdiri dari 4 tanaman sampel, sehingga jumlah keseluruhan tanaman yang digunakan adalah sebanyak 120 tanaman sawi. Rincian perlakuan adalah sebagai berikut :

$\mathrm{P} 0=$ Tanpa pemupukan

P1 = Pemberian pupuk NPK Mutiara $166 \mathrm{Kg}$ $\mathrm{Ha}^{-1}$

P2 = Pemberian pupuk NPK Mutiara $277 \mathrm{Kg}$ $\mathrm{Ha}^{-1}$

P3 = Pemberian pupuk NPK Mutiara 388 Kg $\mathrm{Ha}^{-1}$

P4 = Pemberian pupuk Urea $111 \mathrm{Kg} \mathrm{Ha}^{-1}$

P5 = Pemberian pupuk Urea $222 \mathrm{Kg} \mathrm{Ha}^{-1}$

P6 = Pemberian pupuk Urea $333 \mathrm{Kg} \mathrm{Ha}^{-1}$

P7 = Pemberian pupuk Gandasil D 111 Kg liter $^{-1}=200 \mathrm{~mL}_{\text {tanaman }}{ }^{-1}$

P8 = Pemberian pupuk Gandasil D $222 \mathrm{Kg}$ liter $^{-1}=200 \mathrm{~mL}$ tanaman $^{-1}$
P9 = Pemberian pupuk Gandasil D $333 \mathrm{Kg}$ liter $^{-1}=200 \mathrm{~mL}$ tanaman $^{-1}$

\section{Pelaksanaan Penelitian}

Persiapan Lahan. Tanah yang digunakan untuk media persemaian berupa tanah top soil yaitu tanah lapisan atas yang telah dibersihkan dari kotoran seperti gulma, akar, dan dedaunan kering.

Penanaman. Benih disemai di tray semai sampai berumur 2 minggu. Pengisian media tanam dilakukan pada polibag ukuran $30 \mathrm{x}$ $30 \mathrm{~cm}$, tanah yang digunakan adalah tanah top soil dicampur dengan kompos dengan perbandingan $2: 1$, jarak antar polibag adalah $25 \mathrm{~cm}$ dan jarak antar barisan yaitu $25 \mathrm{~cm}$. Pemberian label pada polibag dilakukan satu hari sebelum pemberian perlakuan.

Pemeliharan. Pemeliharaan tanaman meliputi penyiraman, penyiangan, pengendalian hama dan pengendalian penyakit dan pemanenan dilakukan pada umur 45 hari setelah tanam.

Perlakuan Pupuk. Frekuensi pemberian pupuk NPK mutiara dan pupuk urea dilakukan setelah 1 MST. Pupuk NPK mutiara, pupuk urea dan pupuk Gandasil D diberikan setelah tanaman dipindah tanam ke polibag.

Variabel Pengamatan. Variabel yang diamati pada penelitian terdiri dari variabel utama dan variabel penunjang. Variabel utama meliputi: tinggi tanaman $(\mathrm{cm})$, jumlah daun (helai), warna daun, panjang akar $(\mathrm{cm})$, lingkar tanaman $(\mathrm{cm})$, berat 
segar (gram), berat kering (gram), dan luas daun $\left(\mathrm{cm}^{2}\right)$.

\section{Analisis Data}

Data yang diperoleh secara kuantitatif dilakukan analisis ragam (ANOVA). Uji $\mathrm{F}$ taraf nyata 5\% digunakan untuk menguji keragaman. Apabila terdapat keragaman yang nyata maka dilanjutkan dengan uji Jarak Berganda Duncan untuk membandingkan di antara perlakuan.

\section{HASIL DAN PEMBAHASAN}

\section{Tinggi Tanaman}

Tinggi tanaman dengan perlakuan jenis pupuk anorganik disajikan pada Tabel
1. Hasil pengamatan tinggi tanaman menunjukkan pengaruh perlakuan jenis pupuk anorganik terhadap pertumbuhan dan hasil sawi pagoda pada pengamatan 1 , 2, 3, dan 4 MST. Berdasarkan data rata-rata tinggi tanaman perlakuan P6 adalah perlakuan yang memberikan tinggi tanaman tertinggi yaitu 13,88 $\mathrm{cm}$. Sedangkan perlakuan P3 adalah perlakuan yang memberikan tinggi tanaman terpendek yaitu $10,87 \mathrm{~cm}$. Hal ini disebabkan karena tanaman sudah mendapat unsur hara yang cukup dari tanah untuk menghasilkan pertumbuhan yang optimal.

Tabel 1. Tinggi tanaman dengan pemberian jenis pupuk anorganik (cm)

\begin{tabular}{lcccc}
\hline \multirow{2}{*}{ Perlakuan } & \multicolumn{4}{c}{ Tinggi Tanaman (cm) } \\
\cline { 2 - 5 } & 1 MST & 2 MST & 3 MST & 4 MST \\
\hline P0 (Tanpa Pemupukan) & 5,83 & 9,97 & 12,18 & 12,67 \\
P1 (NPK Mutiara 166 Kg Ha-1) & 5,66 & 9,25 & 12,23 & 12,75 \\
P2 (NPK Mutiara 277 Kg Ha-1) & 5,51 & 9,54 & 12,70 & 13,43 \\
P3 (NPK Mutiara 388 gg Ha$^{-1}$ ) & 4,67 & 8,26 & 10,70 & 10,87 \\
P4 (Urea 111 Kg Ha-1) & 5,08 & 8,04 & 10,33 & 11,98 \\
P5 (Urea 222 $\mathrm{Kg} \mathrm{Ha}^{-1}$ ) & 5,16 & 8,42 & 11,23 & 13,40 \\
P6 (Urea 333 Kg Ha-1) & 5,52 & 9,21 & 11,71 & 13,88 \\
P7 (Gandasil D 111 Kg liter-1) & 5,75 & 8,21 & 11,86 & 13,08 \\
P8 (Gandasil D 222 Kg liter-1) & 4,93 & 7,66 & 10,81 & 12,46 \\
P9 (Gandasil D 333 Kg liter-1) & 5,75 & 8,70 & 12,01 & 12,72 \\
Nilai Standar Deviasi & 0,39 & 0,73 & 1,22 & 0,84 \\
\hline
\end{tabular}

Pertumbuhan tinggi tanaman tidak berbeda nyata menunjukkan bahwa tanaman berada pada zona cukup (Rosmala et al., 2017). Menurut Syamsuddin dan Tambing (2010) tanaman yang berada pada zona cukup dan perlakuan penambahan unsur hara hanya akan meningkatkan kandungan unsur tersebut di dalam jaringan tanaman tetapi hanya sedikit atau tidak berpengaruh sama sekali terhadap peningkatan hasil panen.

Pertumbuhan tinggi tanaman yang optimal pada sawi disebabkan oleh penyerapan faktor nutrisi yang optimal khususnya penyerapan unsur hara nitrogen dan kalium yang bermanfaat bagi tinggi tanaman sawi. Hal tersebut menunjukkan

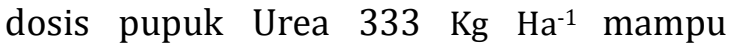
menyuplai nitrogen sesuai jumlah yang 
dibutuhkan untuk pertumbuhan sawi pagoda. Hal ini sejalan dengan pendapat Erawan et al. (2013) unsur $\mathrm{N}$ memiliki peranan penting dalam fase vegetatif tanaman, nitrogen merupakan unsur hara esensial untuk pembelahan dan perpanjangan sel, sehingga unsur $\mathrm{N}$ merupakan penyusun protoplasma yang terdapat dalam jaringan seperti titik tumbuh.

\section{Jumlah Daun}

Jumlah daun dengan pemberian pupuk anorganik disajikan dalam Tabel 2.
Berdasarkan Tabel 2 perlakuan P2 memberikan jumlah daun terbanyak (13 helai), sedangkan perlakuan P4 menunjukan jumlah daun paling sedikit (10 helai). Hal ini menunjukkan bahwa tidak semua unsur nitrogen yang bersumber dari pupuk anorganik mampu menyuplai kebutuhan unsur hara tanaman sawi selama proses pertumbuhan tanaman sawi. Hal ini disebabkan karena sebagian besar unsur nitrogen dari pupuk anorganik tersebut hilang melalui penguapan maupun tercuci oleh air (Erawan et al., 2013).

Tabel 2. Jumlah daun dengan pemberian jenis pupuk anorganik (Helai)

\begin{tabular}{lcccc}
\hline \multirow{2}{*}{ Perlakuan } & \multicolumn{3}{c}{ Jumlah Daun (Helai) } \\
\cline { 2 - 4 } & 1 MST & 2 MST & 3 MST & 4 MST \\
\hline P0 (Tanpa Pemupukan) & 6 & 8 & 9 & 11 \\
P1 (NPK Mutiara 166 Kg Ha-1) & 7 & 8 & 10 & 11 \\
P2 (NPK Mutiara 277 Kg Ha-1) & 7 & 8 & 10 & 13 \\
P3 (NPK Mutiara 388 Kg Ha-1) & 6 & 7 & 8 & 12 \\
P4 (Urea 111 Kg Ha') & 6 & 6 & 8 & 10 \\
P5 (Urea 222 Kg Ha-1) & 6 & 8 & 10 & 13 \\
P6 (Urea 333 Kg Ha-1) & 6 & 8 & 11 & 12 \\
P7 (Gandasil D 111 Kg liter-1) & 6 & 8 & 9 & 12 \\
P8 (Gandasil D 222 Kg liter-1) & 6 & 7 & 9 & 12 \\
P9 (Gandasil D 333 Kg liter-1) & 6 & 8 & 9 & 13 \\
Nilai Standar Deviasi & 0,42 & 0,69 & 0,94 & 0,99 \\
\hline
\end{tabular}

Tabel 2 menunjukan perlakuan P2 (NPK Mutiara $388 \mathrm{Kg} \mathrm{Ha}^{-1}$ ) memberikan jumlah daun terbanyak selama 4 kali pengamatan yaitu sebesar 13 helai daun. Hal ini disebabkan kandungan pada pupuk NPK mutiara yaitu unsur posfor (P) berperan dalam pembentukan ATP yang digunakan untuk pertumbuhan sel dan unsur kalium (K) berperan sebagai aktivator enzim yang terlibat dalam proses sintesis protein dan karbohidrat. Peningkatan penyerapan unsur hara K oleh akar tanaman dapat meningkatkan karbohidrat sehingga dapat meningkatkan pertumbuhan jumlah daun (Manan dan $\mathrm{Al}$ Mahfudz, 2015).

Faktor yang mempengaruhi pertumbuhan jumlah daun yaitu ketersediaan air, nutrisi, dan cahaya matahari untuk melakukan proses fotosintesis. Daun merupakan organ tanaman tempat mensintesis makanan untuk kebutuhan tanaman dan tempat penyimpanan cadangan makanan, daun 
memiliki klorofil yang berperan dalam melakukan fotosintesis. Semakin banyak jumlah daun, proses fotosintesis juga akan meningkat. Nitrogen merupakan unsur hara utama yang dibutuhkan oleh tanaman untuk pertumbuhan dan pembentukan organ vegetatif tanaman seperti batang, daun, dan akar (Suhastyo dan Raditya, 2019). Tanaman mampu menyuplai unsur nitrogen sesuai jumlah yang dibutuhkan untuk proses pertumbuhan dan perkembangan pada tanaman sawi hijau, disebabkan unsur hara nitrogen sangat berperan dalam pertumbuhan vegetatif tanaman misalnya tinggi tanaman dan jumlah daun tanaman sawi hijau (Ngantung et al., 2018).

\section{Warna Daun}

Berdasarkan Tabel 4 tanaman sawi menunjukan warna daun skala 4 dan 5 . Skala 4 menandakan tanaman mendapatkan unsur hara yang cukup untuk pertumbuhan dan perkembangannya. Pemberian pupuk $\mathrm{N}$ berdasarkan hasil pengukuran warna daun dengan BWD skala 4 dapat menghemat pemakaian pupuk 15-20\% dari takaran yang umum digunakan petani tanpa menurunkan hasil (Erythrina, 2016). Skala 5 menandakan tanaman terlalu subur yang ditandai dengan warna daun hijau tua. Pengukuran warna daun dengan BWD skala diatas 4 maka tidak perlu dilakukan pemupukan susulan karena kebutuhan unsur hara sudah tercukupi. Pemberian unsur hara $\mathrm{N}$ yang berlebihan meningkatkan kerentanan tanaman terhadap hama dan penyakit, maka rekomendasi pupuk spesifik lokasi menjadi sangat penting (Erythrina, 2016).

Pertumbuhan tanaman yang diindikasikan warna daun berkaitan erat dengan zat hara yang diserap tanaman dan jumlah air pada media yang melarutkan unsur hara tersebut (Manan dan $\mathrm{Al}$ Mahfudz, 2015). Menurut Tando (2018) Tanaman nonlegum menyerap Nitrogen $(\mathrm{N})$ dari dalam tanah dalam bentuk nitrat $\left(\mathrm{NO}_{3}{ }^{-}\right)$ atau ammonium $\left(\mathrm{NH}_{4}{ }^{+}\right)$, pada tanah pertanian nitrat merupakan bentuk senyarwa $\mathrm{N}$ yang paling banyak diserap tanaman. Protein sel-sel vegetatif sebagian besar bersifat fungsional daripada struktural dan bentuknya tidak stabil sehingga selalu mengalami pemecahan dan reformasi. Peranan N selain sintesa protein, $\mathrm{N}$ juga merupakan bagian yang tidak dapat terpisahkan dari molekul klorofil dan pemberian $\mathrm{N}$ dalam jumlah cukup akan mengakibatkan pertumbuhan vegetatif yang subur dan warna daun hijau gelap. Pemberian $\mathrm{N}$ berlebih pada lingkungan tertentu dapat menunda fase generatif tanaman bahkan tidak terjadi sama sekali. Secara fungsional, nitrogen berperan sebagai penyusun enzim yang sangat besar peranannya dalam proses metabolisme, karena enzimnya tersusun dari protein. Nitrogen merupakan unsur mobile dalam tanaman yang berarti bahwa protein fungsional yang mengandung $\mathrm{N}$ dapat terurai pada bagian tanaman yang lebih tua, kemudian diangkut menuju jaringan muda. 
Tabel 3. Warna daun dengan pemberian jenis pupuk anorganik

\begin{tabular}{|c|c|c|}
\hline \multirow[t]{2}{*}{ Perlakuan } & \multicolumn{2}{|c|}{ Warna Daun } \\
\hline & 2 MST & 4 MST \\
\hline P0 (Tanpa Pemupukan) & 5 & 5 \\
\hline P1(NPK Mutiara $166 \mathrm{Kg} \mathrm{Ha}^{-1}$ ) & 5 & 5 \\
\hline P2 (NPK Mutiara $277 \mathrm{Kg} \mathrm{Ha}^{-1}$ ) & 4 & 5 \\
\hline P3 (NPK Mutiara $388 \mathrm{Kg} \mathrm{Ha}^{-1}$ ) & 4 & 4 \\
\hline P4 (Urea $111 \mathrm{Kg} \mathrm{Ha}^{-1}$ ) & 5 & 4 \\
\hline P5 (Urea $222 \mathrm{Kg} \mathrm{Ha}^{-1}$ ) & 4 & 5 \\
\hline P6 (Urea $333 \mathrm{Kg} \mathrm{Ha}^{-1}$ ) & 5 & 5 \\
\hline P7 (Gandasil $111 \mathrm{Kg} \mathrm{liter-1)}^{-1}$ & 4 & 5 \\
\hline P8 (Gandasil $222 \mathrm{Kg} \mathrm{liter-1}^{-1}$ ) & 4 & 5 \\
\hline P9 (Gandasil $333 \mathrm{Kg} \mathrm{liter-1}^{-1}$ ) & 4 & 5 \\
\hline Nilai Standar Deviasi & 0,51 & 0,42 \\
\hline
\end{tabular}

Minggu ke 4 sebelum pemanenan, perlakuan P0 (tanpa pupuk) dan P4 (Urea $111 \mathrm{Kg} \mathrm{Ha}^{-1}$ ) mengalami gejala defisiensi unsur hara yang ditandai dengan daun tua mengalami perubahan warna menjadi hijau kekuningan. Tanah kurang mengandung $\mathrm{N}$ tersedia, maka seluruh tanaman akan berwarna hijau pucat atau kuning (klorosis). Hal ini dapat terjadi karena rendahnya produksi klorofil dalam tanaman. Daun tertua lebih dahulu menguning karena $\mathrm{N}$ dipindahkan dari bagian tanaman ini menuju ke daerah ujung pertumbuhan. Daun bagian bawah tanaman

Berdasarkan Tabel 4 perlakuan P7

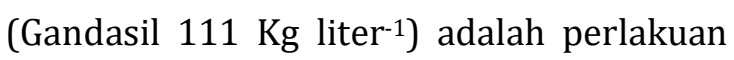
yang memberikan panjang akar terpanjang yaitu 23,42 cm, sedangkan perlakuan P5 (urea $222 \mathrm{Kg} \mathrm{Ha}^{-1}$ ) adalah perlakuan yang memberikan akar pendek terhadap tanaman sawi pagoda yaitu $15,25 \mathrm{~cm}$. Hal ini dapat disebabkan karena kandungan $\mathrm{P}$ dan $\mathrm{K}$ dalam pupuk cenderung menghasilkan panjang akar yang seragam. Akar tanaman sawi mengalami pemanjangan sesuai dengan volume media yang mengalami defisiensi dengan gejala awal klorosis di bagian ujung dan cepat merambat melalui tulang tengah daun menuju batang. Daun tepi tetap hijau untuk beberapa saat. Bila defisiensi menjadi semakin berat, daun tertua kedua dan ketiga mengalami pola defisiensi serupa dan daun tertua menjadi coklat sempurna. Bila defisiensi $\mathrm{N}$ dapat dilacak pada awal pertumbuhan, maka dapat diatasi dengan suatu penambahan pupuk yang mengandung $\mathrm{N}$ sehingga dapat berpengaruh pada hasil panen (Tando, 2018).

\section{Panjang Akar}

tanam. Pupuk P dan K yang diaplikasikan pada tanaman akan mempengaruhi sebaran akar karena akar tanaman sawi berbentuk serabut. Berdasarkan Tabel 4 perlakuan P7 (Gandasil $111 \mathrm{Kg}$ liter-1) memberikan panjang akar terpanjang sebesar 23,42 cm. Hal ini disebabkan pupuk daun gandasil D mengandung $15 \%$ Posfor yang dapat mempengaruhi pertumbuhan akar. Faktor yang mempengaruhi pertumbuhan akar adalah unsur hara posfor (P), karena selain berfungsi sebagai perangsang buah dan biji 
unsur hara ini juga berperan dalam perkembangan sistem perakaran tanaman (Anggara, 2017). Fosfor bagi tanaman berguna untuk merangsang pertumbuhan akar yang dipengaruhi oleh suplai fotosintat dari daun. Hasil fotosintat akan dipergunakan untuk memperluas zona perkembangan akar dan memacu pertumbuhan akar primer baru. Faktor yang mempengaruhi pola penyebaran akar adalah suhu tanah, aerasi, ketersediaan air, dan ketersediaan unsur hara (Simanullang et al., 2019).

Tabel 4. Panjang akar, lingkar tanaman, dan luas daun dengan pemberian jenis pupuk anorganik

\begin{tabular}{lccc}
\hline \multicolumn{1}{c}{ Perlakuan } & Panjang Akar (cm) & Lingkar Tanaman (cm) & Luas Daun (cm ${ }^{2}$ ) \\
\hline P0 (Tanpa Pemupukan) & 16,25 & 2600 & $20,90 \mathrm{bc}$ \\
P1 (NPK Mutiara 166 Kg Ha-1) & 17,12 & 28.17 & $22,74 \mathrm{bc}$ \\
P2 (NPK Mutiara 277 Kg Ha-1) & 19,92 & 20,83 & $25,34 \mathrm{abc}$ \\
P3 (NPK Mutiara 388 Kg Ha-1) & 15,42 & 22,83 & $15,45 \mathrm{c}$ \\
P4 (Urea 111 Kg Ha-1) & 18,79 & 26,08 & $20,62 \mathrm{bc}$ \\
P5 (Urea 222 Kg Ha-1) & 15,25 & 28,00 & $24,29 \mathrm{abc}$ \\
P6 (Urea 333 Kg Ha-1) & 17,42 & 34,17 & $33,91 \mathrm{a}$ \\
P7 (Gandasil D 111 Kg liter-1) & 23,42 & 29,83 & $29,32 \mathrm{ab}$ \\
P8 (Gandasil D 222 Kg liter-1) & 17,46 & 27,50 & $26,01 \mathrm{ab}$ \\
P9 (Gandasil D 333 Kg liter-1) & 17,00 & 30,92 & $26,20 \mathrm{bc}$ \\
Nilai Standar Deviasi & 2,42 & 3,84 & 19,84 \\
\hline
\end{tabular}

\section{Lingkar Tanaman}

Berdasarkan Tabel 4 perlakuan P6 (Urea $333 \mathrm{Kg} \mathrm{Ha}^{-1}$ ) adalah perlakuan yang memberikan diameter terbesar yaitu 34,17 cm, sedangkan perlakuan P2 (NPK Mutiara $388 \mathrm{Kg} \mathrm{Ha}^{-1}$ adalah perlakuan yang memberikan diameter terkecil yaitu 20,83 $\mathrm{cm}$. Hal ini disebabkan kandungan nitrogen pada urea lebih tinggi yaitu sebesar 46\%, dibandingkan kandungan N pada NPK dan Gandasil (16\% dan 20\%).

Nitrogen berperan dalam proses pertumbuhan tanaman sawi seperti tinggi tanaman, jumlah daun, diameter batang, luas daun, berat segar tanaman, dan berat kering. Penyerapan unsur $\mathrm{N}$ oleh akar tanaman akan menyebabkan peningkatan jumlah daun karena proses fotosintesis berlangsung pada daun sehingga berpengaruh terhadap pertumbuhan batang dan luas daun. Jumlah daun dan luas daun meningkat maka diameter tanaman akan besar. Pertumbuhan diameter yang besar maka menunjukkan bahwa daya hantar zat nutrisi tanaman untuk melakukan fotosintesis dapat terjadi lebih cepat. Hal ini disebabkan terdapat jaringan pengangkut yang lebih banyak untuk mentransfer zat untuk proses fotosintesis (Anggara, 2017).

Berdasarkan Tabel 5 perlakuan P6 (Urea $333 \mathrm{Kg} \mathrm{Ha}^{-1}$ ) adalah perlakuan yang memberikan berat basah tertinggi yaitu 90,50 g. Sedangkan perlakuan P3 (NPK Mutiara $388 \mathrm{Kg} \mathrm{Ha}^{-1}$ ) merupakan perlakuan yang memberikan berat basah terendah yaitu $44,50 \mathrm{~g}$. 
Tabel 5. Berat basah, berat kering, dan produktivitas dengan emberian jenis pupuk anorganik

\begin{tabular}{lccc}
\hline \multicolumn{1}{c}{ Perlakuan } & Berat Basah (g) & Berat Kering (g) & Produktivitas (Ton Ha-1) \\
\hline P0 (Tanpa Pemupukan) & 51,00 & 4,17 & 5,61 \\
P1 (NPK Mutiara 166 Kg Ha-1) & 67,83 & 6,42 & 7,47 \\
P2 (NPK Mutiara 277 Kg Ha-1) & 81,75 & 7,33 & 9,03 \\
P3 (NPK Mutiara 338 Kg Ha-1) & 44,50 & 4,08 & 4,89 \\
P4 (Urea 111 Kg Ha-1) & 49,83 & 4,75 & 5,49 \\
P5 (Urea 222 Kg Ha-1) & 78,00 & 6,92 & 8,60 \\
P6 (Urea 333 Kg Ha-1) & 90,50 & 7,42 & 10,00 \\
P7 (Gandasil D 111 Kg liter-1) & 78,92 & 6,67 & 8,70 \\
P8 (Gandasil D 222 Kg liter-1) & 66,25 & 5,50 & 7,30 \\
P9 (Gandasil D 333 Kg liter-1) & 81,25 & 6,83 & 8,97 \\
Nilai Standar Deviasi & 15,82 & 1,28 & 1,75 \\
\hline
\end{tabular}

Hal ini diduga karena tanaman sawi merupakan salah satu jenis tanaman sayuran yang memiliki kandungan air yang tinggi (Erawan et al., 2013). Berat segar tanaman sawi dipengaruhi oleh diameter batang, kandungan air yang banyak dan unsur hara yang terserap oleh daun tanaman pada saat proses metabolisme terjadi (Jayati dan Susanti, 2019). Sejalan dengan hasil penelitian ini, Sarif et al. yaitu tanaman mengandung protoplasma yang berfungsi menyimpan air dan $\mathrm{CO}_{2}$. Protoplasma mengikat banyak air sehingga akar dan menyebabkan kapasitas penyerapan lebih baik dibandingkan dengan perlakuan yang lain. Menurut Pangaribuan (2012) komoditas sayuran daun pada jumlah daun akan berpengaruh terhadap berat segar tajuk. Semakin banyak jumlah daun maka akan menunjukkan berat segar tajuk yang tinggi, berat basah tanaman juga semakin besar.

Produktivitas tanaman sawi pagoda dengan pemberian berbagai jenis pupuk anorganik disajikan pada Tabel 5. Produksi tanaman sawi pada tahun 2017 di Tasikmalaya sebesar 5,64 Ton $\mathrm{Ha}^{-1}$ dengan
(2015) menyatakan bahwa bobot segar tanaman meningkat disebabkan kandungan air dan unsur hara pada daun cukup optimal, air sangat berperan dalam turgiditas sel, sehingga sel-sel daun akan membesar. Menurut Istarofah dan Salamah (2017) yang mempengaruhi berat basah yaitu ketersediaan unsur hara yang optimal di dalam tanah untuk diserap oleh akar. Penyebab berat basah tanaman meningkat berat basah juga akan meningkat. Sehingga pada perlakuan P6 mampu meningkatkan daya ikat air dan menyerap unsur hara oleh luasan lahan 168 Ha (BPS Jawa Barat 2017). Berdasarkan Tabel 5 perlakuan P6 (Urea $333 \mathrm{Kg} \mathrm{Ha}^{-1}$ ) merupakan perlakuan yang memberikan produktivitas terbesar yaitu 10 Ton/Ha, sedangkan perlakuan P3 (NPK Mutiara $388 \mathrm{Kg} \mathrm{Ha}^{-1}$ ) merupakan perlakuan yang memberikan produktivitas terendah yaitu sebesar 4,89 Ton $\mathrm{Ha}^{-1}$. Hal ini disebabkan pemberian nitrogen pada dosis yang tepat dapat meningkatkan pertumbuhan tanaman, meningkatkan metabolisme tanaman, pembentukan protein, karbohidrat, pembentukan klorofil yang menyebabkan warna daun menjadi 
lebih hijau, dan meningkatkan ratio pucuk akar, akibatnya pertumbuhan dan produksi tanaman meningkat (Sarif et al., 2015).

\section{Berat Kering}

Pemberian pupuk anorganik mampu memenuhi kebutuhan unsur hara tanaman sawi sehingga pertumbuhan vegetatif tanaman baik jumlah daun, tinggi tanaman, dan luas daun meningkat yang mana dapat mempengaruhi berat kering tanaman (Sarif et al., 2015). Berdasarkan Tabel 5 perlakuan P6 (Urea $333 \mathrm{Kg} \mathrm{Ha}^{-1}$ ) adalah perlakuan yang memberikan berat kering tertinggi yaitu 7,42 g. Sedangkan perlakuan P3 (NPK Mutiara $388 \mathrm{Kg} \mathrm{Ha}^{-1}$ ) merupakan perlakuan yang memberikan berat kering terendah yaitu $4,08 \mathrm{~g}$.

Berat kering semakin besar menunjukkan proses fotosintesis berlangsung lebih efisien dan produktifitas serta perkembangan sel-sel jaringan semakin tinggi dan cepat, sehingga pertumbuhan tanaman menjadi lebih baik (Sarif et al., 2015). Nitrogen yang terkandung pada pupuk urea sebagai penyusun protein berperan dalam memacu pembelahan jaringan meristem dan merangsang pertumbuhan akar dan perkembangan daun (Sarif et al., 2015).

Berat kering tanaman sawi menunjukkan unsur hara yang disintesis, optimalisasi unsur hara yang disintesis oleh tanaman sawi berdampak pada jumlah helai daun dan ukuran daun tanaman sawi. Ukuran daun yang besar dan jumlah helai daun yang banyak menandakan optimalnya sintesis unsur hara dan peningkatan bahan kering yang lebih banyak (Anggara, 2017). Peningkatan tinggi tanaman dan jumlah daun mengakibatkan luas daun meningkat. Peningkatan pertumbuhan organ vegetatif seperti peningkatan jumlah daun, penambahan tinggi tanaman, serta pemanjangan akar dan efisiensi distribusi asimilat ke bagian-bagian tanaman akan berdampak pada peningkatan bobot kering yang terbentuk (Helmei dan Anjarwati, 2016).

\section{Luas Daun}

Berdasarkan Tabel 5 perlakuan P6 memberikan luas daun terluas, namun tidak berbeda nyata dengan perlakuan P2, P5, P7, dan P8. Sedangkan perlakuan P3 adalah perlakuan yang menunjukkan luas daun terkecil meskipun tidak berbeda nyata dengan perlakuan P0, P1, P3, P4, P5, dan P9. Tabel 9 menunjukan perlakuan P6 (Urea $333 \mathrm{Kg} \mathrm{Ha}^{-1}$ ) merupakan perlakuan dengan luas daun terbaik yaitu sebesar $33,91 \mathrm{~cm}^{2}$. Hal ini disebabkan penyerapan unsur $\mathrm{N}$ oleh akar optimal sehingga berpengaruh terhadap luas daun. Selain itu kandungan N pada pupuk urea sangat tinggi sehingga unsur hara untuk pertumbuhan tanaman tercukupi karena tanaman sawi sangat membutuhkan unsur hara $\mathrm{N}$ untuk pertumbuhan daun. Menurut Siswadi dan Teguh (2013) menyatakan bahwa pertumbuhan akar mampu menyerap nutrisi yang tersedia terutama unsur $\mathrm{N}$ yangsangat berperan dalam pembentukan 
daun sehingga daun tumbuh lebih lebar dan menyebabkan luas daun yang lebih besar.

Bagian tanaman sawi yang dikonsumsi yaitu berupa daun sehingga pupuk yang sesuai untuk peningkatan jumlah dan luas daun yaitu pupuk urea. Semakin besar ukuran lebar daun, maka semakin banyak menghasilkan karbohidrat sebagai sumber energi bagi tanaman sawi. Semakin banyak energi yang yang dihasilkan tanaman sawi, maka semakin besar kemampuan tanaman menyerap unsur hara dari media tanam (tanah) dan luas daun meningkat maka semakin cepat terjadi laju fotosintesis, sehingga tanaman dapat tumbuh lebih cepat (Pasaribu, 2019).

Berdasarkan Tabel 5 perlakuan P3 (NPK Mutiara $388 \mathrm{Kg} \mathrm{Ha}^{-1}$ ) memberikan luas daun terendah yaitu sebesar 15,45 $\mathrm{cm}^{2}$. Unsur hara yang berlebihan pada media tanam sawi pakcoy, sehingga pertumbuhan lebar daun tanaman sawi pakcoy tidak dapat berlangsung secara optimal. Kelebihan unsur hara mengakibatkan tanaman lebih sensitif terhadap iklim dan lebih mudah terserang hama (Pasaribu, 2019).

Kadar ketersediaan air berkaitan dengan proses penyerapan unsur hara oleh tanaman pada proses metabolisme. Tanaman memberikan respon terhadap ketersediaan air yang ada dengan menambah luas daun. Tanaman juga melakukan proses fotosintesis dan transpirasi yang lebih aktif akibat penyerapan air yang tinggi oleh tanaman.
Semakin banyak air yang tersedia untuk fotosintesis maka semakin tinggi unsur hara yang masuk kedalam tanaman karena pengaruh tingginya transpirasi, akan semakin mempertinggi pertumbuhan vegetatif tanaman (Manan dan Al Mahfudz, 2015). Menurut Sarif et al. (2015) unsur Nitrogen berperan penting dalam pertumbuhan vegetatif tanaman, selain itu nitrogen dibutuhkan pada setiap pembentukan tunas atau perkembangan batang dan daun pada tanaman. Bila pasokan $\mathrm{N}$ cukup, daun tanaman akan tumbuh besar dan memperluas permukaan daun yang tersedia untuk proses fotosintesis. Pasokan nitrogen yang tinggi akan mempercepat pengubahan karbohidrat menjadi protein dan dipergunakan menyusun dinding sel. Pemupukan nitrogen mempunyai pengaruh nyata terhadap peluasan daun, terutama pada lebar dan luas daun. Tanaman akan meningkatkan laju pertumbuhan daunnya supaya bisa menangkap cahaya secara maksimal sehingga proses fotosintesis di dalam daun dapat berjalan dengan lancar (Bella et al., 2015).

\section{SIMPULAN}

Dari hasil pengamatan yang telah dilakukan maka dapat ditarik kesimpulan sebagai berikut :

1. Pemberian beberapa jenis pupuk anorganik terhadap pertumbuhan dan hasil tanaman sawi pagoda 
memberikan pertumbuhan dan hasil yang optimal pada parameter tinggi tanaman, jumlah daun, warna daun, panjang akar, diameter tanaman, berat segar, dan berat kering tanaman sawi pagoda dan pertumbuhan yang paling optimal pada parameter luas daun sebesar $33,91 \mathrm{~cm}^{2}$.

2. Respon tanaman dalam penyerapan pupuk anorganik yang optimal untuk pertumbuhan berat segar, berat kering, diameter tanaman dan luas daun adalah perlakuan dengan pemberian pupuk urea dengan dosis $333 \mathrm{Kg} \mathrm{Ha}^{-1}$.

\section{DAFTAR PUSTAKA}

Anggara, D. (2017). Pengaruh jenis campuran media tanam terhadap pertumbuhan tanaman sawi (Brassicae juncea L). Skripsi. Mataram: Universitas Islam Negeri Mataram.

Bella, P. P., Sitawati., \& Mudiji, S. (2015). Pengaruh biourine sapi dan berbagai dosis $\mathrm{N}$ terhadap tanaman kailan (Brassicae oleraceae L.). Jurnal Budidaya Pertanian, 3(1), 1-8.

BPS. (2017). Produki hortikultura sayuran dan buah semusim Provinsi Jawa Barat. [Internet]. https://jabar.bps.go.id/piblication/20 18/10/10/ba04045e3610dfd2eb680 297/produksi-hortikultura-sayurandan-buah-semusim-provinsi-jawabarat-2017.html [diakses 14 November 2019].
Erawan, D., Yani O. W., \& Bahrun, A. (2013). Pertumbuhan dan hasil tanaman sawi (Brassicae juncea L.) pada berbagai dosis pupuk urea. Jurnal Agroteknos, 3(1), 19-25.

Erythrina. (2016). Bagan warna daun: alat untuk meningkatkan efisiensi pemupukan nitrogen pada tanaman padi. Jurnal Litbang Pert 35(1), 1-10.

Helmei, \& Anjarwati. (2016). Pengaruh macam media dan takaran pupuk kambing terhadap pertumhan dan hasil sawi hijau (Brassicae rapa L.). Jurnal Vegetalika 6(1), 35-45.

Irmawati. (2018). Respon pertumbuhan dan produksi tanaman caisin (Brassicae Jencea L.) dengan perlakuan jarak tanam. Journal of Agritech Science 2(1), 1-7.

Istarofah, \& Salamah, Z. (2017). Pertumbuhan tanaman sawi hijau (Brassicae juncea L.) dengan pemberian kompos berbahan dasar daun paitan (Thitonia diversifolia). Jurnal Biosite 3(1), 39-46.

Jayati, R. D., \& Susanti, I. (2019). Perbedaan pertumbuhan dan produktivitas tanaman sawi pagoda menggunakan pupuk organik cair dari eceng gondok dan limbah sayur. Jurnal Biosilampari $1(2), 73-77$.

Manan, A. A., \& Al Mahfudz, W. D. P. (2015). Pengaruh volume air dan pola vertikultur terhadap pertumbuhan 
dan hasil sawihijau (Brassicae juncea L.). Jurnal Agroteknologi 12(1), 33-43. Ngantung, B. A. J., Rondonuwu, J. J., \& Kawulusan, I. R. (2018). Respon tanaman sawi hijau (Brassicae juncea L.) terhadap pemberian pupuk organik dan anorganik di Kelurahan Rurukan Kecamatan Tomohon Timur. Jurnal Eugenia 24(1), 1-9.

Pangaribuan, D. H. (2012). Pengaruh pupuk organik cair terhadap pertumbuhan dan produksi sayuran kangkung, bayam dan caisim. Prosiding Seminar Nasional PERHORTI ISBN: 978-977925-1265-6. Hal 300-306

Rosmala, A., Mutiarawati, T., \& Nuraini, A. (2017). Pengaruh kompos campuran sampah organik dengan berbagai kotoran ternak terhadap pertumbuhan dan hasil wortel (Daucus carrota L.) kultivar lokal Cipanas. Jurnal Hexagro 1(2), 36-40.

Sarif, P., Hadid, A., \& Wahyudi, I. (2015). Pertumbuhan dan hasil tanaman sawi (Brassicae juncea L.) akibat pemberian berbagai dosis pupuk urea. Jurnal Agrotekbis, 3(5), 585-591.
Simanullang, A. Y., Kartini, N. L., \& Kesumadewi, A. A. I. (2019). Pengaruh pupuk organik dan anorganik terhadap pertumbuhan dan hasil tanaman sawi hijau (Brassicae rapa. L). Jurnal Agrotrop 9(2), 166 - 177.

Siswadi, \& Teguh, Y. (2013). Uji hasil tanaman sawi pada berbagai media tanam secara hidroponik. Jurnal Innofarm 2(1), 44-50.

Suhastyo, A. A, \& Raditya, T. F. (2019). Respon pertumbuhan dan hasil sawi pagoda (Brassicae narinosa) terhadap pemberian mol daun kelor. Jurnal Agroteknologi Research 3(1), 56-60.

Syamsuddin, L., \& Tambing, Y. (2010). Pertumbuhan dan hasil bawang daun (allium fistulosum L.) pada berbagai dosis pupuk kandang. Jurnal Agroland 17(2),144-148.

Tando, E. (2018). Upaya efisiensi dan peningkatan ketersediaan nitrogen dalam tanah serta serapan nitrogen pada tanaman padi sawah. Jurnal Buana Sains 18(2), 171-180. 